\title{
Persistence Evaluation of Some Insecticidal Plants and Application Rate to Maize Weevil Damage in Stored Maize Grain
}

\author{
Khalid Kinati*1 Abraham Tadesse ${ }^{2} \quad$ Ashok Thakur $^{3}$ \\ 1.Department of Plant Science, Bedelle College of Agriculture and Forestry, Mettu University, Ethiopia \\ 2.Sasakawa Global 2000 Ethiopia, Addis Abeba \\ 3.Haramaya University, School of Plant Science, Haramaya, Ethiopia \\ P.O.Box 318, Mettu, Ethiopia
}

\begin{abstract}
A study was conducted to evaluate the persistence of insecticidal effects of some of botanicals and application on adult parent mortality of maize weevil in infested maize grain. Seven botanicals (Azadirachta indica (neem), Melia azedarach (melia), Parthenium hysterophorus (parthenium), Calpurnia aurea (calpurnia), Vernonia amygdalina (bitter leaf), Carica papaya (papaya) and Dichrocephala integrifolia) were tested each at three different rates viz, $2.5,5$ and $10 \% \mathrm{w} / \mathrm{w}$. Malathion $5 \%$ dust at $0.05 \%$ as standard check and untreated check were included for comparison. Twenty unsexed adult weevils were re introduced to treated maize grains at 90 DAT and parent mortality was recorded at 93,100,107, 114, and 121 DAT. The experiment was laid out in a completely randomized design (CRD) in factorial arrangement and replicated four times. The result showed that $A$. indica, $M$. azedarach and $D$. integrifolia at all rates caused equal cumulative mortality $(100 \%)$ with the synthetic insecticide, but the time required to totally kill the insects varied. All treatments caused significantly higher mortality than the untreated check after four months of storage.
\end{abstract}

DOI: $10.7176 / \mathrm{JBAH} / 11-2-04$

Publication date: January $31^{\text {st }} 2021$

\section{INTRODUCTION}

Maize (Zea mays L.) is the most important cereal crop in Sub-Saharan Africa (SSA) and an important staple food for more than 1.2 billion people in SSA and Latin America (IITA, 2009). It provides $20 \%$ of the world's food calories and 15\% of all food crop protein (Meseret, 2011). According to the report from CIMMYT and IITA (2011), maize production is projected to double in the developing countries by the year 2050 and its global production surpasses all crops by 2025 . In Ethiopia, out of $81.97 \%$ of land covered by cereals, $16.61 \%$ was maize, ranked second next to teff and it accounted for $24.5 \%$ of $87.29 \%$ yield obtained from cereals ranking first in production. This indicates that about $1,963,179.51$ hectare of land was cultivated with maize and 49,861,254.95 quintal was produced with $25.4 \mathrm{qt} /$ ha of yield (CSA, 2011).

Despite the worldwide continuous increase in the land coverage, production and demand for maize, there are multi-faceted production bottlenecks including arthropod pests in field and storage. More than 30 species of arthropods are recorded on stored maize in Ethiopia. The major insect pests of stored maize are the maize weevil (Sitophilus zeamais Motsch.), the Angoumois grain moth (Sitotroga cerealella Olivier), the larger grain borer (Prostephanus truncatus Horn), the tropical warehouse moth (Ephestia cautella Hubner), Indian meal moth (Plodia interpunctella Hubner), flour beetles (Tribolium spp.), and Cryptolestes spp. and etc. Some of these insects infest the ripening maize crop before harvest and at storage, and multiply further during storage (Abraham, 1991).

S. zeamais causes distinctive damage by making holes into the maize grain that is about $1 \mathrm{~mm}$ in size in which the adult female deposit eggs. The holes are sealed with a gelatinous waxy secretion. The eggs, larval and pupal stages of the insect take place within the grain after which the emerging adult weevil comes out of the grain via the holes, leaving visible hole on the grain (Rees, 2004; Sahaf et al., 2008) which invites infection and infestation by secondary pathogens and insects, respectively. Maize weevil damage results indirect food loss ready for consumption or cause cash loss. Maize weevil damage on maize grains also reduces the viability of the seeds as the larvae and adult consumes the embryo. Reports from Ethiopia indicate that post-harvest losses average 20 to $30 \%$ of grain dry weight in maize stored on farm due to the maize weevil. Grain damage levels of up to $100 \%$ have been reported in some grain samples from farm stores after 6 to 8 months of storage in the Bako area, West Shoa (Abraham, 1991).

The indiscriminate use of many synthetic insecticides, which is common practice among farmers, is associated with problems such as resistance of insect pests, food and food product contamination with toxic residues, increased cost of application, handling hazards, environmental contamination, biodiversity erosion and other negative impacts call for the development of alternative storage pest management. The use of locally available plants with insecticidal properties and inert materials to limit insect development and damage in stored grains is a common practice in developing countries (Firdisa and Abraham, 1999). In Ethiopia, farmers use different botanicals to protect their maize grain from insect infestation (Abraham, 2003), while the types of botanicals used vary from place to place. Although there is low implementation owing to low awareness amongst 
farmers, some studies made in the last decade have proved that there are certain botanicals which are reported to be effective at certain rates against the maize weevil on stored maize such as neem, melia, Mexican tea powder, datura, triplex and etc.

Presently, we can confidently say that farmers and responsible bodies are not using these botanicals as the first option due to different reasons, like absence of firm recommendation, low confidence, lack of knowledge of botanical preparation, and unavailability of recommended plants in the area. Therefore, studies on alternative botanicals which can be conveniently utilized by farmers, need to be given due consideration for stored grain pest management. Current study, therefore, undertaken with the objective of evaluating persistence efficacy of some of the locally available plants and their effective doses in reducing the adult parent mortality after 3 months of application.

\section{MATERIALS AND METHODS}

\subsection{Description of the Laboratory}

The experiment was conducted in the laboratory of National Maize Research Program at Bako, West Shoa Zone of the Oromia Regional State from September 2012 to April 2013. Laboratory conditions during the experimental season indicated that the mean daily minimum, maximum and average air temperatures of the laboratory was 21.7, 27.8 and $24.7^{\circ} \mathrm{C}$, respectively. The minimum, maximum and average relative humidity was $52.99,68.25$ and $59.05 \%$, respectively.

\subsection{Preparation of Experimental Materials}

Whole grain of maize hybrid BH-541 at 12-13\% moisture content was used to rear the maize weevils. The seeds were sieved to remove any dirt, dust or broken seeds and stored at $-20 \pm 2{ }^{\circ} \mathrm{C}$ for two weeks to disinfest them from any infestations. The disinfested grains were placed in plastic bags and kept for two more weeks at the experimental conditions for acclimatization as used by Girma (2006).

Adults with known age were obtained by culturing 500 unsexed adult maize weevils in two liter plastic jars containing $500 \mathrm{~g}$ of disinfested maize grains and maintained under laboratory conditions. The jars were covered with muslin cloth and fixed with rubber band to allow aeration and prevent possible escape of weevils. The insects were allowed for one week to oviposit before they were sifted and placed on another set of grain kept for the same purpose. Starting from the commencement of progeny development in each jar, new emerged weevils were removed daily until the progeny emergence ceased. Those emerged on the same day were transferred to fresh grain in other containers reserved with whole grain and kept at the experimental conditions (Abraham, 1991).

Seven botanicals were evaluated for their efficacy to maize weevil (Table 1). Fruits of $A$. indica and $M$. azedarach were collected from Dire Dawa and Jigjiga, respectively. The leaves of $V$. amygdalina and $D$. integrifolia were collected from the road side in Nekemte town; P. hysterophorus and C. papaya from Sasiga around Nekemte and $C$. aurea from Hareto near Shambu town. The plant parts were allowed to dry under shade at room temperature. The dried samples were ground separately to fine powder using mortar and pestle and the powder passed through a $0.25 \mathrm{~mm}$ mesh sieve to obtain a fine dust. Prepared powders then separately maintained in a plastic bag and stored in the refrigerator at $13^{\circ} \mathrm{C}$ for future use.

Table 1. List of botanicals and their parts used

\begin{tabular}{|l|l|l|l|}
\hline No & \multicolumn{1}{|c|}{ Scientific name (Family) } & Common name & Part used \\
\hline 1 & Azadirachta indica A. Juss (Meliaceae) & Neem & Seed \\
\hline 2 & Parthenium hysterophorus L. (Asteraceae) & Parthenium & leaf and stem \\
\hline 3 & Melia azedarach L. (Meliaceae) & Melia & Seed \\
\hline 4 & Calpurnia aurea Ait (Fabaceae) & Calpurnia & Leaf \\
\hline 5 & Vernonia amygdalina Del (Compositae) & Bitter leaf & Leaf \\
\hline 6 & Carica papaya L. (Caricaceae) & Papaya & Leaf \\
\hline 7 & Dichrocephala integrifolia Kuntze (Asteraceae) & Not available & leaf and stem \\
\hline
\end{tabular}

\subsection{Treatment Application}

Two hundred grams of disinfested and conditioned maize grain was added into glass jars of $250 \mathrm{ml}$ capacity. Three different rates of each botanical viz, $2.5 \%, 5 \%$ and $10 \%(\mathrm{w} / \mathrm{w})$ were weighed and added onto the grain in each of the jars with lids allowing ventilation. Malathion $5 \%$ dust at $0.05 \% \mathrm{w} / \mathrm{w}$ and untreated controls were included for comparison. The jars were well shaken to ensure proper mixture of grains with botanical and insecticide dust.

Adult weevils of 1 to 3 days old were thoroughly mixed and randomly picked for use. Thirty unsexed adult maize weevils were introduced into each glass jar and the jars were covered with muslin cloth and fixed by rubber band to allow sufficient ventilation and to prevent escape of the weevils. The experiment was laid out in completely randomized design (CRD) in four replications arranged factorially. The glass jars were maintained in the laboratory at room temperature. Temperature and relative humidity of the room were recorded daily until the end of the experiment 


\subsection{Data Collection and Analysis}

Treated jars were previously used for data collection for other studies and grains remaining in each jar, 20 unsexed adult weevils from the laboratory stock were re introduced at 90 DAT. Adult mortality was recorded at 3, 10, 17, 24 and 31 days after introduction (i.e. 93, 100, 107, 114, and 121 DAT). On the $31^{\text {st }}$ day all of the insects were removed and counted as the same procedure employed in the preceded experiment. Count data for adult mortality were converted to percentage, corrected mortality was computed and angular transformed. The transformed data were then subjected to analysis of variance by using GeneStat version 15 computer software program. Mean separation was done by using Tukey test at 0.05 .

\section{RESULT AND DISCUSSION}

The botanicals and their rates of application had significantly different persistence and affected the mortality of adult weevils when introduced at 90 DAT.

Following 93 DAT, the highest adult mortality $(92.37 \%)$ was on grains treated with malathion and the lowest mortality $(8.82 \%)$ on the $C$. aurea $2.5 \%$ (Table 2$)$. No mortality was observed on untreated grains. Meliaazedarach and $A$. indica, both at $10 \% \mathrm{w} / \mathrm{w}$, caused relatively higher mortalities than the other botanical treatments. C. aurea, $V$. amygdalina and $P$. hysterophorus at $2.5 \%$ and $5 \%$ rates caused less mortality, but significantly more effective than the untreated check.

A. indicaat $10 \% \mathrm{w} / \mathrm{w}$ was as effective as the synthetic insecticide (malathion) at $100 \mathrm{DAT}$ and both of them caused $100 \%$ adult mortality (Table 3 ). Some of the treatments did not show significant differences when applied at $2.5 \%$ and $5 \% \mathrm{w} / \mathrm{w}$. Dichrocephala integrifolia and M. azedarach at $10 \% \mathrm{w} / \mathrm{w}$ caused relatively higher mortality than the rest treatments.

Table 2. Effects of botanicals and rates on percent of adult weevil mortality at 93 DAT

\begin{tabular}{|c|c|c|c|}
\hline \multirow{3}{*}{ Treatments } & \multicolumn{3}{|c|}{ Percent adult weevil mortality } \\
\hline & \multicolumn{3}{|c|}{ Rates $(\%$ w/w) } \\
\hline & 2.5 & 5 & 10 \\
\hline C. aurea & $(8.82) 16.85^{1}$ & $(11.32) 19.17^{\mathrm{kl}}$ & (17.63) $24.57^{\mathrm{h}-\mathrm{k}}$ \\
\hline D. integrifolia & (26.51) $30.93^{\mathrm{f}-\mathrm{i}}$ & (38.03) $38.06^{\text {def }}$ & $(59.47) 50.48^{\mathrm{b}}$ \\
\hline V. amygdalina & $(11.45) 19.68^{\mathrm{jkl}}$ & $(10.07) 18.23^{\mathrm{kl}}$ & (22.70) $28.35^{\text {ghi }}$ \\
\hline M. azedarach & $(30.33) 33.39^{\text {efg }}$ & (27.83) $31.82^{\text {fgh }}$ & $(53.16) 46.82^{b c}$ \\
\hline A. indica & (40.46) $39.49^{\text {cde }}$ & (44.21) $41.66^{\mathrm{cd}}$ & $(64.54) 53.48^{\mathrm{b}}$ \\
\hline C. papaya & (20.33) $26.69^{g-j}$ & (24.08) $29.36^{\mathrm{ghi}}$ & (26.51) $30.93^{\mathrm{f}-\mathrm{i}}$ \\
\hline P. hysterophorus & $(8.88) 17.18^{\mathrm{kl}}$ & (10.13) $18.56^{\mathrm{kl}}$ & $23.89^{\mathrm{i}-1}$ \\
\hline Malathion & $(92.37) 74.20^{\mathrm{a}}$ & $(92.37) 74.20^{\mathrm{a}}$ & $(92.37) 74.20^{\mathrm{a}}$ \\
\hline Untreated check & $(0.00) 0.00^{\mathrm{m}}$ & $(0.00) 0.00^{\mathrm{m}}$ & $(0.00) 0.00^{\mathrm{m}}$ \\
\hline $\operatorname{LSD}(5 \%)$ & 3.90 & & \\
\hline $\mathrm{CV}(\%)$ & 8.70 & & \\
\hline
\end{tabular}

Values in parentheses are untransformed means; mean separation was done with angular transformed values; means followed by the same letter(s) are not significantly different from each other at $5 \%$ level of significance by Tukey.

At 107 DAT, $A$. indica at 2.5 and $5 \%, D$. integrifolia at $10 \%$ and $M$. azedarach at $10 \%$ resulted in $100 \%$ mortality while the mortality caused in the untreated check was $0 \%$ (Table 4). All of the treatments caused significantly higher mortality than the untreated check and D. integrifolia at $5 \% \mathrm{w} / \mathrm{w}$ caused relatively higher mortality than the rest botanical treatments.

Following 114 DAT the highest (100\%) mortality was observed in D. integrifolia at $2.5 \%$ and $5 \% \mathrm{w} / \mathrm{w}$ while the mortality recorded in the untreated check was $0 \%$ (Table 5). All of the other treatments also caused significantly higher mortality than the untreated check. The increase in efficacy of $D$. integrifolia as the rate increase in the present study is similar with the result of Pone et al. (2013) who reported that the ethanolic leaf extract of $D$. integrifolia inhibited embryonation, egg hatch and larval survival of gastro-intestinal nematode parasite of mice (Heligmosomoides bakeri) at various concentrations when compared with the control and the extract with higher concentrations showed more activity than the extract with lower concentration. 
Table 3. Effects of botanicals and rates on percent of adult weevil mortality at $100 \mathrm{DAT}$

\begin{tabular}{|c|c|c|c|}
\hline \multirow{3}{*}{ Treatments } & \multicolumn{3}{|c|}{ Percent adult weevil mortality } \\
\hline & \multicolumn{3}{|c|}{ Rates (\% w/w) } \\
\hline & 2.5 & 5 & 10 \\
\hline C. aurea & $(18.95) 25.41^{\mathrm{k}}$ & $(23.95) 28.94^{\mathrm{ij}}$ & $(36.58) 37.08^{\mathrm{gh}}$ \\
\hline D. integrifolia & $(54.34) 47.51^{\mathrm{efg}}$ & $(77.37) 62.02^{\mathrm{cd}}$ & $(94.93) 76.99^{b}$ \\
\hline V. amygdalina & $(24.21) 29.27^{\mathrm{ij}}$ & $(21.45) 27.44^{\mathrm{ij}}$ & (46.71) $43.09^{e-h}$ \\
\hline M. azedarach & $(61.97) 51.97^{\mathrm{de}}$ & $(56.97) 49.02^{e f}$ & $(94.93) 76.99^{b}$ \\
\hline A. indica & $(87.37) 69.27^{\mathrm{bc}}$ & $(87.24) 69.35^{b c}$ & $(100.00) 90.00^{\mathrm{a}}$ \\
\hline C. papaya & $(41.97) 40.30^{\mathrm{fgh}}$ & $(49.47) 44.69^{e-h}$ & $(54.34) 47.51^{\mathrm{efg}}$ \\
\hline P. hysterophorus & $(19.08) 25.65^{\mathrm{j}}$ & $(21.58) 27.64^{\mathrm{ij}}$ & $(34.21) 35.76^{\text {hij }}$ \\
\hline Malathion & (100.00) $90.00^{\mathrm{a}}$ & $(100.00) 90.00^{a}$ & (100.00) $90.00^{\mathrm{a}}$ \\
\hline Untreated check & $(0.00) 0.00^{\mathrm{k}}$ & $(0.00) 0.00^{\mathrm{k}}$ & $(0.00) 0.00^{\mathrm{k}}$ \\
\hline $\operatorname{LSD}(5 \%)$ & 5.53 & & \\
\hline $\mathrm{CV}(\%)$ & 8.30 & & \\
\hline
\end{tabular}

Values in the parentheses are untransformed means; mean separation was done with angular transformed values; means followed by the same letter(s) are not significantly different from each other at $5 \%$ level of significance by Tukey.

At 121 DAT, significantly the highest adult mortality was observed in M. azedarach at $2.5 \%$ and $5 \% \mathrm{w} / \mathrm{w}$, while there were no dead weevils recorded in the untreated check (Table 6). The efficacy of each treatment was increased in increase with rate of application and duration. This might be due to the fact that botanicals have long persistence effect. Tigist (2004) also suggested that natural pesticides could have direct or delayed insecticidal effects. The delayed effect is inhibition of reproduction and development by hampering oviposition, larval penetration into the seed and adult emergence. Generally, the present result suggests that all of the tested botanicals remained effective against the maize weevil at least for four months.

Table 4. Effects of botanicals and rates on percent of adult weevil mortality at 107 DAT

\begin{tabular}{|c|c|c|c|}
\hline \multirow{3}{*}{ Treatments } & \multicolumn{3}{|c|}{ Percent adult weevil mortality } \\
\hline & \multicolumn{3}{|c|}{ Rates (\% w/w) } \\
\hline & 2.5 & 5 & 10 \\
\hline C. aurea & $(34.14) 35.65^{\mathrm{g}}$ & $(34.08) 35.57^{g}$ & $(69.54) 56.59^{\text {cd }}$ \\
\hline D. integrifolia & $(75.92) 60.64^{c}$ & $(94.93) 76.99^{b}$ & (100.00) $90.00^{\mathrm{a}}$ \\
\hline V. amygdalina & $(41.91) 40.31^{\mathrm{fg}}$ & (40.39) $39.40^{\mathrm{fg}}$ & $(63.16) 52.69^{\text {cde }}$ \\
\hline M. azedarach & (75.92) $60.64^{c}$ & (67.11) $55.04^{\mathrm{cd}}$ & (100.00) $90.00^{\mathrm{a}}$ \\
\hline A. indica & $(100.00) 90.00^{\mathrm{a}}$ & (100.00) $90.00^{\mathrm{a}}$ & nd \\
\hline C.papaya & $(52.11) 46.26^{\mathrm{ef}}$ & $(58.36) 49.85^{\mathrm{de}}$ & (67.11) $55.12^{\mathrm{cd}}$ \\
\hline P. hysterophorus & (34.21) $35.78^{\mathrm{g}}$ & (43.09) $41.02^{\mathrm{fg}}$ & $(49.47) 44.69^{\mathrm{ef}}$ \\
\hline Malathion & & & \\
\hline Untreated check & $(0.00) 0.00^{\mathrm{h}}$ & $(0.00) 0.00^{\mathrm{h}}$ & $(0.00) 0.00^{\mathrm{h}}$ \\
\hline $\operatorname{LSD}(5 \%)$ & 4.51 & & \\
\hline $\mathrm{CV}(\%)$ & 5.7 & & \\
\hline
\end{tabular}

Values in parentheses are untransformed means; mean separation was done with angular transformed values; means followed by the same letter(s) are not significantly different from each other at $5 \%$ level of significance (Tukey). nd:- indicates no data was recorded since all the weevils dead previously.

Table 5. Effects of botanicals and rates on percent of parent adult mortality at 114 DAT

\begin{tabular}{|c|c|c|c|}
\hline \multirow{3}{*}{ Treatments } & \multicolumn{3}{|c|}{ Percent adult weevil mortality } \\
\hline & \multicolumn{3}{|c|}{ Rates (\% w/w) } \\
\hline & 2.5 & 5 & 10 \\
\hline C. aurea & $(49.34) 44.62^{\mathrm{hi}}$ & $(44.21) 41.65^{\mathrm{i}}$ & $(87.30) 69.23^{\mathrm{bcd}}$ \\
\hline D. integrifolia & (100.00) 90.00a & (100.00) $90.00^{\mathrm{a}}$ & nd \\
\hline V. amygdalina & $(59.61) 50.59^{\mathrm{ghi}}$ & (59.34) $50.52^{\text {ghi }}$ & $(78.36) 62.47^{\text {cde }}$ \\
\hline M. azedarach & $(89.87) 71.44^{b c}$ & $(94.93) 76.99^{b}$ & 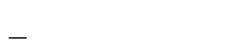 \\
\hline A. indica & & & \\
\hline C. papaya & (57.17) $49.25^{\mathrm{ghi}}$ & $(67.24) 55.25^{\mathrm{efg}}$ & (77.24) $61.77^{\mathrm{def}}$ \\
\hline P. hysterophorus & $(49.34) 44.62^{\mathrm{hi}}$ & (64.61) $53.53^{\mathrm{e}-\mathrm{h}}$ & $(63.42) 52.88^{\text {fgh }}$ \\
\hline Malathion & & & \\
\hline Untreated check & $(0.00) 0.00^{\mathrm{j}}$ & $(0.00) 0.00^{\mathrm{j}}$ & $(0.00) 0.00^{j}$ \\
\hline $\operatorname{LSD}(5 \%)$ & 4.75 & & \\
\hline $\mathrm{CV}(\%)$ & 5.7 & & \\
\hline
\end{tabular}


Values in parentheses are untransformed means; mean separation was done with angular transformed values; means followed by the same letter(s) are not significantly different from each other at $5 \%$ level of significance (Tukey). nd:- indicates that no data was recorded since all the weevils dead previously.

Table 6. Effects of botanicals and rates on percent of parent adult mortality at 121 DAT

\begin{tabular}{|c|c|c|c|}
\hline \multirow{3}{*}{ Treatments } & \multicolumn{3}{|c|}{ Percent adult weevil mortality } \\
\hline & \multicolumn{3}{|c|}{ Rates $(\%$ w/w) } \\
\hline & 2.5 & 5 & 10 \\
\hline C. aurea & $(64.54) 53.56^{\mathrm{f}}$ & $(54.35) 47.51^{\mathrm{f}}$ & $(94.93) 76.99^{b}$ \\
\hline D. integrifolia & nd & & \\
\hline V. amygdalina & $\overline{(78.55)} 62.56^{\mathrm{e}}$ & (85.99) $68.69^{\text {cde }}$ & (93.62) $75.58^{\mathrm{bc}}$ \\
\hline M. azedarach & $(100.00) 90.00^{\mathrm{a}}$ & (100.00) $90.00^{\mathrm{a}}$ & 40 \\
\hline A. indica & & & \\
\hline C. papaya & $\overline{(65.99)} 54.50^{\mathrm{f}}$ & (79.87) $63.63^{\mathrm{e}}$ & $(89.87) 71.73^{\mathrm{bcd}}$ \\
\hline P. hysterophorus & $(65.79) 54.22^{\mathrm{f}}$ & $(83.62) 66.29^{\mathrm{de}}$ & $(79.80) 63.36^{\mathrm{e}}$ \\
\hline Malathion & & & \\
\hline Untreated check & $(0.00) 0.00^{\mathrm{g}}$ & $(0.00) 0.00^{\mathrm{g}}$ & $(0.00) 0.00^{\mathrm{g}}$ \\
\hline $\operatorname{LSD}(5 \%)$ & 4.15 & & \\
\hline $\mathrm{CV}(\%)$ & 4.3 & & \\
\hline
\end{tabular}

Values in parentheses are untransformed means; mean separation was done with angular transformed values; means followed by the same letter(s) are not significantly different from each other at $5 \%$ level of significance (Tukey). nd:- indicates that no data was recorded since all the weevils dead previously.

\section{SUMMARY AND CONCLUSIONS}

Plants with insecticidal properties are locally available; however, farmers lack adequate know-how about their benefits. Unlike synthetic chemicals, botanicals do not affect the environment, have no residual effects and are inexpensive. In this study, all the tested botanicals showed insecticidal properties with varying degrees and were significantly different from the untreated check.

Significant differences in the percentage of damaged grains and grain weight losses were noted among the botanicals. Among the botanical treatments the highest level of seed damage was recorded in C. aurea at $2.5 \%$ and the highest level of grain weight loss was recorded in grains treated with $C$. aurea and $V$. amygdalina both at $2.5,5$ and $10 \% \mathrm{w} / \mathrm{w}$, while there was no seed damage and weight loss recorded in grains treated with $A$. indica at all rates. Generally, percentage of damaged grains and grain weight losses were lower in all botanical treatments than in the untreated check. On the other hand, the botanicals did not negatively affect the seed germination.

Although this study showed existence of the potentials of some botanicals in controlling the maize weevil on maize grain, further research is needed to determine the active ingredients and mode of action of the botanicals, and it is essential that trials be also carried out to investigate the responses which would be observed under real farm conditions, such as fluctuating ambient climatic conditions, continuous disturbance of grain by the family itself and a complex of insect pest species and also the effects of store design and structure since this laboratory based and short duration study may not be enough for the final recommendation. It is also important to investigate how long these botanicals can further remain active in reducing $\mathrm{F}_{1}$ progeny development, seed damage, weight loss and retaining viability.

\section{AKNOWLEDGEMENTS}

The authors are grateful to Ethiopian Ministry of Science and Higher Education for funding, Wollega University and Haramaya University for facilitation of research activities and Bako National Maize Research Center for providing laboratory and other required facilities.

\section{REFERENCES}

Abraham Bilum and Abate Bekele, 2002. Storing grains as a survival strategy of small farmers in Ethiopia. Journal of International Agricultural and Extension Education, 9:777-831.

Abraham Tadesse, 1991. The biology, significance and control of the maize weevil, Sitophilus zeamais Motsch., (Coleoptera: Curculionidae) on stored maize. An MSc Thesis Presented to the School of Graduate Studies of Alemaya University of Agriculture. 250pp.

Abraham Tadesse, 2003. Studies on some non-chemical insect pest management options on farm-stored maize in Ethiopia. A PhD Thesis presented to the School of Graduate Studies of Giessen University, Germany. 246 $\mathrm{pp}$.

Adane Kebede and Abraham Tadesse, 1995. Evaluation of some botanicals against the maize weevil, Sitophilus zeamais Motsch. on stored sorghum at Bako. Pp.120-126. In: Proceeding of the Third Annual Conference of the Crop Protection Society of Ethiopia, 18- 19 May 1995, Addis Ababa, Institute of Agricultural Research. 
Adedapo, A. A., Jimoh, F. O., Koduru, S. K., Afolayan, A. J. and Masika, P. J. 2008. Admixtures against Sitophilus oryzae (Linn.). Neem Newsletter, 3(2):13-14.

Araya Gebresillasie, 2007. Evaluation of powder and essential oils of some botanical plants for their efficacy against Zabrotes subfasciatus (Boheman) (Coleoptera: Bruchidae) on haricot bean (Phaseolus vulgaris L.) under laboratory condition in Ethiopia. An MSc Thesis Presented to the School of Graduate Studies of Addis Ababa University, Ethiopia. 93pp.

Asawalam E.F. and Hassanali A., 2006. Constituents of the essential oil of Vernonia amygdalina as Maize Weevil Protectants. Tropical and Subtropical Agro ecosystems, 6:95-102.

Asmare Dejene, 2002. Evaluation of some botanicals against maize weevil ( $S$. zeamais)on stored sorghum. Pp. 419-427. In: Abraham Tadesse (ed.), 2008. Increasing crop production through improved plant protectionVolume I. Proceedings of the $14^{\text {th }}$ Annual conference of Plant Protection Society of Ethiopia (PPSE), 19-22 December 2006. Addis Ababa, Ethiopia. PPSE and EIAR, Addis Ababa, Ethiopia. 598 pp.

Chalachew Teshale and Tesfaye Mohammed, 2012.Preliminary phytochemical screening and evaluation of antibacterial activity of Dichrocephala integrifolia (L.f) O. kuntze. Journal of Intercult Ethnopharmacol,1(1):3034.

Chifundera K., 1998. Livestock Diseases and the Traditional Medicine in the Bushi Area, Kivu Province, Democratic Republic of Congo. African Study Monographs, 19(1):13-33.

CIMMYT (International Wheat and Maize Improvement Center) and IITA (International Institute of Tropical Agriculture), 2011. Maize-Global alliance for improved food security and the livelihoods of the resource poor in the developing world. CIMMYT and IITA to the CGIAR Consortium Board. In collaboration with CIAT, ICRISAT, IFPRI, ILRI, IRRI, the World Agroforestry Centre, National Agricultural Research Institutes. 4 PP.

CSA (Central Statistical Authority), 2011. Agricultural Sample Survey: report on area and production of major crops (private peasant holdings, Meher season). Statistical Bulletin(1) Addis Ababa, Ethiopia.

El-Atta H.A. and Ahmed A., 2002. Comparative effects of some botanicals for the control of the seed weevil Caryedon serratus (Olivier) (Coleoptera: Bruchidae). Journal of Applied Entomology, 126: 577-582.

Ferdu Azerefegne, Demissew Kitaw and Birhane Abay, 2001. Major insect pests of maizeand their management: A review. pp. 89-96. In: Proceeding of the Second National MaizeWorkshop of Ethiopia 12-16 November 2001, Addis Ababa, Ethiopia.

Ferede Negasi, 1994. Studies on the economic importance and pest control of bean bruchids in haricot bean, Phaseolus vulgaris in Eastern and Southern Shoa. An M.Sc. Thesis Presented to the School of Graduate Studies of Alemaya University of Agriculture. 105pp.

Fikremariam Abebe, 2005. Evaluation of Botanicals and Varietal Resistance against Maize Weevil (Sitophilus zeamais Motsch.) (Coleoptera: Curculionidae) in Stored Maize Grain.An MSc Thesis Presented to the School of Graduate Studies of Alemaya University, Ethiopia. 69pp.

Firdisa Eticha and Abraham Tadesse, 1999.Effects of some botanicals and other materials against the maize weevil (Sitophilus zeamais Motsch.) on stored maize. 9 pp. In: Abraham Tadesse (ed.), 2008. Increasing crop production through improved plant protection-Volume I. Proceedings of the $14^{\text {th }}$ Annual conference of Plant Protection Society of Ethiopia (PPSE), 19-22 December 2006. Addis Ababa, Ethiopia. PPSE and EIAR, Addis Ababa, Ethiopia. 598 pp.

Girma Demisse 2006. Field Infestation by Sitophilus zeamais Motsch. (Coleoptera: Curculionidae) and its Management on stored maize at Bako, Western Ethiopia. An MSc Thesis Presented to the School of Graduate Studies of Alemaya University, Ethiopia. 91pp.

IITA (International Institute of Tropical Agriculture),2009. Maize crop. http://www.iita.org/maize. Accessed on $4^{\text {th }}$ August 2013.

Kabeh J. D. and Jalingo, M. G. D. S.S ., 2007. Pesticidal Effect of Bitter Leaf Plant (Vernonia amygdalina)(Compositae) Leaves and Pirimiphos-methyl on Larvae of Callosobruchus maculatus (Coleoptera: Bruchidae) and Sitophilus zeamais (Coleoptera: Curculionidae). International Journal of Agriculture and Biology, 3: 452-454.

Melanie W., Ivonne R., Armin B., Carmen B., Taye Tessema, Arunava G., Inga M. and Christian U., 2007. Insecticidal Effects of Parthenium hysterophorus Extracts Rich in Terpenoids and Phenolic Acids (abstract). 112-113.In: Utilizationof diversity in land use systems: Sustainable and organic approaches to meet human needs" Tropentag, October 9-11, 2007, Witzenhausen.

Meseret Bekele, 2011. Effect of fermentation on quality protein maize-soybean blends for the production of weaning food, M.Sc. Thesis, Addis Ababa University, Addis Ababa, Ethiopia. 75 pp.

Mulungu L. S., Lupenza, G., Reuben, S. O. W. M. and Misengu. R. N., 2007. Evaluation of botanical products as stored grain protectant against maize weevil, Sitophilus zeamais on maize. Journal of Entomology, 4(3):258262.

Narong Ch., 2003. Protection of Stored Products with Special Reference to Thailand. Assumption University 
Journal of Technology, 7(1):31-47.

Ofuya T. I., 1990. Oviposition deterrence and ovicidal properties of some plant powdersagainst Callosobruchus maculatus in stored cowpea (Vigna unguiculata) seeds. Journal of Agricultural Science, 115:343-345.

Oudhia P. 1998. Parthenium:A curse for the biodiversity of Chhattisgarh plain. 7 pp.In: Arshad J., Sobiya S. and Shazia S., 2007. Causes of rapid spread of Parthenium hysterophorus L. in Pakistan and possible control measures; a review. Pakistan Journal of Botany, 39(7): 2611-2618.

Paulsamy S., Vijayakumar K.K., Murugesan M., Padmavathy S. and Senthilkumar P., 2006. Ecological status of medicinal and other economically important plants in the Shola understories of Nilgiris, the Western Ghats. Natural Product Radiance, 6(1):55-61.

Pone J. W., Payne,V. K., Mbogning,T. G., Komtangi,M. C., Yondo,J., Ngangout,A. M., M. Mpoame, and Bilong CF Bilong, 2013.In vitro anthilminthic efficacy of Dichrocephala integrifolia (Asteraceae) extracts on the gastro-intestinal nematode parasite of mice: Heligmosomoides bakeri (Nematoda, Heligmosomatidae). Asian Pacfic Journal of Tropical Biomedicine,3(2):100-104.

Rees D. (ed.), 2004. Insects of Stored Products, CSIRO Publishing, Australia.49pp.

Sahaf B.Z., Moharramipour S., and Meshkatalsadat M.H., 2008. Fumigant Toxicity of Essential oil from Vitex pseudo-negundo against Tribolium castaenum (Herbst) and Sitophilus oryzae (L.), Journal of Asia-Pacific Entomology, 11(4):175-179

Saljoqi A.U.R., Munir K. A., Shah A. K. and Sadu R., 2006. Effects of six plant extracts on rice weevil Sitophilus oryzae in the stored wheat grains.Journal of Agricultural and Biological Science,(1):1-5.

Saxena D. S., 2001. Pesticidal properties of parthenin (from Parthenium hysterophorus) and related compounds. Abstract.Pest Management Science, 57(1):95-101.

Schumutterer H., 1988. Potential of azadirachtin containing pesticides for integrated pestcontrol in developing and industrialized countries. Journal of Insect Physiology, 34:713-718.

Schumutterer H., 1990. Properties and potential of natural pesticides from the neem tree, Azadirachta indica. Annual Revision of Entomology, 35: 271-297.

Semple R. L., 1992. Related problems to use of insecticides: Towards integrated commodity and pest management in grain storage. FAO Corporate Document Repository.Agriculture and Consumer Protection. 92 pp.

Shaheen F.A.,2006. Integrated management of pulse beetle, Callosobruchus chinensis L. (Coleoptera: Bruchidae) attacking stored chickpea. Ph.D. Dissertation, University of Arid Agriculture, Rawalpindi, Pakistan. 226 pp.

Solomon Gebeyehu, 1996. Effect of some botanicals and varietal resistance in the management of Sitophilus sppon stored sorghum. An M.Sc. Thesis Presented to the School of Graduate Studies of Alemaya University. 121 pp.

Somnuk W. and Sangkhae N., 2001. Some Insecticidal Plant Extracts for Controlling Maize Weevil, Sitophilus zeamais Motschulsky (Coleoptera: Curculionidae). Kasetsart Journal of Natural. Science,35:259 - 270

Stoll, G., 2000. Natural crop protection in the tropics. Margraf verlage. $2^{\text {nd }}$ ed. Germany. 388 pp.

Sutherland, J. P., Baharally,V. and Permaul, D., 2002. Use of the botanical insecticide neem, to control the small rice stinkbug (Obalus poecilus) (Dallus, 1851) (Hemiptera: Pentatomidae) in Guyana. Entomotropica, 17:97101.

Umavathi, S. and Manimegalai, M., 2009. Larvicidal activity of the weed plant Parthenium hysterophous L (Compositae) against Aedes aegypti and Culex quinquefasciatus. International Pest Control, 52(4):203-205.

Waka, M., Richard J. H. and Chris C. 2004. Ethno-botanical survey and testing of plants used traditionally against hematophagous insects in Eritrea. Journal of Ethnopharmacology, 95:95-101.

Zorloni A., 2007. Evaluation of plants used for the control of animal ecto-parasites in southern Ethiopia (Oromiya and Somalia regions). A Thesis submitted in fulfillment of the requirements for the degree of Magister Scientiae, University of Pretoria. 135pp. 